\title{
Business Students' Perceptions Of The Impact Of Teaching Practices And Teacher Qualifications On Teacher Quality
}

Amon Okpala, (Email: aokpala@uncfsu.edu), Fayetteville State University Comfort Okpala, (Email: cokpala@shawu.edu), Shaw University

\begin{abstract}
This study examines the role of teaching practices and teacher qualifications in explaining teacher quality. To accomplish this objective, the paper identifies the perceptions of business students on teacher quality, focusing on teacher qualifications and teaching practices components. Data for the study were collected from 218 college students enrolled in business and economics courses in one of the southeastern states university. The results show that the perceptions of students on teacher quality components vary. The emerging themes from the analysis of the students responses are that teaching skills, commitment to student learning, content knowledge and verbal skills are important attributes of a quality teacher.
\end{abstract}

\section{INTRODUCTION}

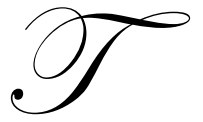

he importance of teacher quality can never be overemphasized given the current national debate and concern regarding what schools can do to positively impact student achievement. Research has shown that students benefit tremendously in the learning process due to several factors. According to Gillies (2002) students benefit academically and socially from cooperative, small-group, interactions with the instructor and amongst themselves. Teachers play a very important role in the learning process. Teaching is a complex problem solving activity and teacher quality is a complex topic, and very hard to define. The definition of teacher quality ranges from a focus on what teachers know and do in their classroom, to how knowledge should be acquired. Nevertheless, previous research results do indicate that students exposed to high quality instruction learn more than other students (Darling-Hammond, 2000; and Goldhaber \& Brewer, 2000). Research studies on teacher quality provide convincing evidence that quality teachers matter, but the evidence on what constitutes a quality teacher are mixed (Hanushek, 1997; and Darling-Hammond, 2000). This study addressed the question of what constitutes a quality teacher by soliciting opinons from college students. The objective is to bridge the research gap by using a mixed-method approach in analyzing the perceptions of college students on teacher quality, with focus on teacher qualifications and teaching practices components.

The primary goal of any institution of higher learning is to employ highly qualified teachers that will produce quality students. Richardson (1996) emphasized that college students' beliefs drive instructional pedagogy. Hart (2002) concluded that college students' beliefs should be taken into consideration in an effort to change teaching practices. One way to improve student achievement and also help facilitate change in the classroom practice is to enhance teacher's content knowledge, and pedagogical skills. The lack of content knowledge is an inhibiting factor to effective instruction. Teachers pedagogical knowledge could be a powerful force in changing the instructional practice.

Given all the above mentioned research issues, this study tries to identify the perceptions of college students on teacher quality, focusing on teacher qualifications and teaching practices components. The paper also analyzes the responses of the students based on gender and age. Finally, the study identifies the main themes from the student's responses pertaining to what constitutes teacher quality. ${ }^{1}$ 


\section{CONCEPTUAL FRAMEWORK}

This study is based on a conceptual model of teacher quality definition adapted from Ingersoll (1999). In Professor Ingersoll's model, teacher quality is defined as a measure of teacher qualifications, teaching practices, and teacher preparation. Teacher qualifications include such components as content knowledge, pedagogical knowledge, teaching credentials, and verbal abilities. Shulman (1987) identified seven areas of professional knowledge for quality teaching. The seven areas include academic subject knowledge, knowledge of teaching strategies, knowledge of curriculum materials and programs, subject-specific knowledge for teaching special students, knowledge of students' characteristics and cultural background, knowledge of the teaching environment, and knowledge of the goals and purposes of teaching. Slavin (2003) stressed that quality teachers need to know their subject matter, how to motivate children, how to use class time effectively, and how to respond to individual differences. Quality teachers must know their subject, and posses the verbal ability to transfer their knowledge to their students.

Research has shown that quality teachers are effective classroom managers, and are critical thinkers that are constantly upgrading and examining their own teaching practices, reading and attending professional conferences to learn new ideas Eby (1994) stated that intentional teachers use a wide variety of instructional methods, experiences, assignments, and materials to ensure that children are achieving all sorts of cognitive objectives. Reynolds (1995) stated that good teachers have the ability to carry out all the tasks involved in effective instruction. A quality teacher must be interested in experimenting with strategies to solve problems of instruction, and observing the results of their actions. Basic to the hot debate on teacher quality is the question of the quality of higher institutions of learning. Institutional variables such as AASB accreditation, state ranking of the school, and others are important measures of the quality of preparing institutions.

As clearly mentioned in the above cited research findings, teacher qualifications, teaching practices, and teacher preparation are all important components that constitute teacher quality. In trying to analyze our students perceptions of what constitutes teacher quality, the authors decided to focus on teacher qualifications and teaching practices components. ${ }^{2}$ Our main goal is to solicit our students views on such issues as, the role of teacher knowledge of the subject, communication/teaching skills, use of instructional technology, assignments, and teachers with advanced degrees in explaining what constitutes a quality teacher from their perspective.

\section{METHOD}

The study is based on a random survey of 218 students enrolled in the School of Business and Economics. The classrooms were randomly selected to include students from different introductory business and economics classes - Principles of Marketing, Principles of Microeconomics and Macroeconomics, Principles of Management, and Principles of Accounting. This institution is a Historically Black Institution, located in South-Eastern United States. ${ }^{3}$ To be included in the study, the participants must give their permission by signing an informed consent document. They also completed a short questionnaire designed to measure their perceptions and beliefs of teacher quality components. All surveys were coded using student identification numbers to maximize confidentiality.

This paper employs the mixed method approach by using both qualitative and quantitative survey questionnaire to examine college students' perceptions on teacher quality components. The added value of mixedmethod approach is that it allows for better data triangulation (Cresswell, 2003). The participants were administered the Teacher Quality Survey (TQS) during the spring semester of 2004 by graduate students who were trained in survey techniques.

The researchers designed and piloted the questionnaire a year before the present study. Several items were deleted as a result of the pilot study, and the final questionnaire consisted of 30 items. The survey questionnaire has two sections. The first section was used to generate demographic information like gender, ethnicity, age, student type, intended teaching level, and college classification. It was also used to generate qualitative data on teacher quality components through open-ended questions. The second section contained a 11-item, 5-point Likert-type scale, which was used to measure the students' perceptions on teacher quality components based on teacher qualification and 
teaching practices. The participants were asked to react to statement by selecting one of the five possible choices: SA $=$ strongly agree, $\mathrm{A}=$ agree, $\mathrm{U}=$ undecided, $\mathrm{D}=$ disagree, $\mathrm{SD}=$ strongly disagree.

Sequential exploratory design method was used to examine the perceptions of college students on teacher quality components. This method of analyses (Cresswell, 2003; Tashakkori \& Tieddlie, 1998) is characterized by an initial phase of qualitative analysis followed by quantitative analysis. The researchers divided the data analysis into two phases. The first phase involved the analysis of the qualitative data. The researchers first identified the main themes from the participants' responses, and examined the data to identify detailed descriptions of the participants. Then, the data were categorized, coded, and grouped according to the themes that emerged. The quantitative data analysis was done to observe the impact of teaching practices and teacher qualification components on the perceptions of business students on teacher quality.

\section{RESULTS}

Table 1 illustrates the demographic characteristics of the study respondents. African American students were the majority, with a participation rate of 78 percent. Also, the female students were more than male students in this survey sample, with a 61.9 percent. Students aged 25 and below accounted for 77.1 percent of the respondents in this study. 52.3 percent of the students indicated the intention of working with a company after graduation, about 44.5 percent intend to pursue graduate studies, and only 3.2 percent indicated the intention of teaching in K-12 levels. About 10.6 percent of the respondents were freshman, 27.5 percent were sophomore, 32.6 percent were junior, 28 percent were seniors, and 1.4 percent were classified as others. A large majority ( 95.9 percent) of the respondents are full-time students.

The analysis of the participants' qualitative responses are illustrated in table 2. When asked to describe what a quality teacher means to them, about thirty-nine (39\%) percent of the college students in the study indicated caring for students and their learning, thirty-four (34\%) percent indicated teaching skills, fourteen (14\%) percent indicated content knowledge, eight (8.0\%) percent indicated dedication to teaching and love of work, and five (5.0\%) percent indicated verbal skills.

The responses of the participants on caring for students and their learning include the following statements:

"A quality teacher is one who cares about all their students, and is willing to help them learn." "A quality teacher to me is highly compassionate, and cares about how their students learn and helps them achieve." And "a quality teacher calls students by their names, and provides assistance to them when needed."

Some of the students' responses on teaching skills include the following statements:

"Inspiring interest in the subject, strong classroom manager, use of different instructional strategies, motivation of students, fair grading practices, and teaching for student learning." "A quality teachers know how to break complex subjects down to the level of their students." "A quality teacher is one that can explain the materials in many ways that students can understand and learn." "A quality teacher understands how students learning, and adapts to meet their needs."

But, when asked to identify the four most important teacher quality component, the respondents indicated caring of students and their learning (89.6\%), teaching skills $(83.2 \%)$, content knowledge (76.8\%), dedication to teaching $(75.3 \%)$, and verbal skills $(75.0 \%)$.

An examining of table 3 revealed that the results of the responses from female and male were quite identical in all components. The responses revealed that 80.7 percent of female respondents perceived that students succeed if teachers know how to teach, while 77.1 percent of men have similar notion. Also, 77.1 percent of female and 73 percent of men have positive perceived that strong verbal skills are key to student achievement. Similar results were found when the respondents were grouped on the bases of age. Table 4 revealed a close similarity in all components of teacher qualification and teaching practices between the responses of respondents that are more than of 25 years old 
and those that are at least 25 years old. According to the results from both tables 3 and 4, the respondents perceived instructional technology as a less effective tool of learning.

The distribution of student responses to what constitutes a quality teacher are illustrated in table 5. According to the figures, 53.7 percent of the respondents strongly agreed to the statement that 'students will succeed if teachers know how to teach,' while about 13.8 percent disagreed to same statement. About 73 percent perceived that strong verbal skills of teachers are key to student achievement. A very small minority (about 11 percent) of students believed that teachers with terminal degree do help students learn more that those without terminal degree. There is a strong agreement that students learn more if teachers are quite knowledgeable of the subject. About 84.4 percent agreed that knowledge of the subject by the teacher do play an important role in student achievement. About 42 percent of the students agreed that students learn more when teachers use instructional technology, while 41 percent were undecided about its impact.

The summary/emerging themes from the student's responses are illustrated on table 6 . The survey showed that 86.7 percent of the participants in this study believed that teaching skills are quite important to student achievement. About 73.7 percent believe that teacher's verbal skill is an important teacher quality component. Commitment to student learning is an important attribute of a quality teacher, while having a terminal degree is not regarded as an important attribute. About 86.2 percent of the respondents believe that a quality teacher is one that is committed to student learning, while about 71.6 percent believe that having a terminal degree is not an important attribute of a quality teacher.

\section{CONCLUSION}

The results of this study do support previous findings that teacher quality is an important educational issue, and that most of the teacher qualifications components are important characteristics of a quality teacher. On teaching practices, the results from the survey of these students did not result to any clear conclusion regarding the role of instructional technology as an important attribute of a quality teacher. More than 50 percent of the respondents agreed that use of all the class time in lecture, and giving of many assignments/home works do not help improve learning.

This study has policy implications to institutions of higher learning, and educational leaders with the goals of hiring quality teachers that will engage in quality teaching to produce quality students. It is apparent from this study that quality teachers must embrace the vision of caring for students and their learning. The primary customers of educational organizations are the students, and quality teachers need to be committed to students and their learning goals. Quality teachers must have the ability to use a variety of instructional methods in their classroom to meet students' learning needs.

\section{ENDNOTES}

1. These themes are based on the summary of qualitative analysis of the responses obtained from the survey

2. The focus of our study is on teacher qualification and teaching practices - ie., instructional pedagogy. We decided to focus on these two because research has shown that teacher qualification and teaching practices are the driving force behind effective student learning.

3. Our research was carried out in a Historically Black Institution of Learning where African American students are the majority of the student body.

\section{REFERENCES}

1. Anderson, L., Blumenfield, P., Pintrich, P., Clark, C., Marx, R., \& Peterson, P. (1995).Educational psychologist for teachers: Reforming our courses, rethinking our Roles. Educational Psychologist, 30(3), 143-157.

2. $\quad$ Cresswell. J. (2002). Research design: qualitative, quantitative and mixed methods Approaches ( $2^{\text {nd }}$ ed.). Thousand Oaks, CA: Sage Publication. 
3. Darling-Hammond, L. (2000). Teacher quality and student achievement: A review of State policy evidence. Journal of Education Policy Analysis, 8(1), 88-114.

4. Duck, L. (2000). The ongoing professional journey. Educational Leadership, 57(8), 43-45.

5. Doyle, M. (1997). Beyond life history as a student: Preservice teachers' beliefs about Teaching and learning. College Student Learning, 31,519-532.

6. $\quad$ Eby, J. (1994). Reflective planning, teaching and evaluation: K-12. New York: Merrill.

7. Flodin, R., \& Klinzing, H., (1990). What can research on teacher thinking contribute to Teacher preparation? A second opinion. Educational Research, 19(4), 15-20.

8. Gillies, Robyn M., (2002). The Residual Effects of Cooperative-Learning Experiences: A Two-Year FollowUp, Journal of Educational Research, vol. 9, \# 1, pp.15-20.

9. Goldhaber, D. \& Brewer, D. (2000). Does teacher certification matter? High school Teacher certification status and student achievement. Educational Evaluation and Policy Analysis, 22(2), 129-146.

10. Gregorian, V. (2001). Teacher education must become colleges' central preoccupation. The Chronicles of Higher Education, B7.

11. Hart, L. (2002). Preservice teachers' beliefs and practices after participating in an Integrated content/method course. School Science \& Mathematics, 102, 4-14.

12. Hanushek, E. (1997). Assessing the effects of school resources on student performance: An update. Educational Evaluation and Policy Analysis, 100(1), 84-117.

13. Ingersoll, R. (1999). The problem of under-qualified teachers in American secondary Schools. Educational Researcher, 28(2), 26-37.

14. Reynolds, A. (1995). The knowledge base of beginning teachers: Education Professionals' expectations versus research findings on learning to teach. Elementary School Journal, 95(3), 199-221.

15. Richardson, V. (1996). The role of attitudes and beliefs in learning to teach. In J. Silcula (Ed.), Handbook of research on teacher education (pp 102-119), New York: Simon \& Schuster.

16. Sabers, D., Selby, L., \& Nolan, P. (1995). Computers empower students with special Needs. Educational Leadership, 53(2)., 82-84.

17. Schmuck, R. (1997). Practical action research for change. Arlington Heights, IL: Skylight.

18. Shulman, L. (1987). Knowledge and teaching: Foundations of the new reform. Harvard Educational Review, 19(2), 4-14.

19. Swafford, J., Jones, G., Thornton, C., Stump, S., \& Miller, D. (1999). Impact of Instructional practices of a teacher change model. Journal of Research and Development in Education, 32, 69-82.

20. Tashakkori, A. \& Teddlie, C. (1998). Mixed methodology: Combining qualitative and Quantitative approaches. Thousand Oaks, CA: Sage Publication. 
Table 1:

The Demographic Characteristics of the Study Participants $(n=218)$

\begin{tabular}{lcr}
\hline Variables & $\mathrm{n}$ & $\%$ \\
\hline Ethnicity & & \\
& & \\
African-Americans & 170 & 22 \\
Others & 48 & 61.9 \\
Gender & 135 & 38.1 \\
Females & 83 & 77.1 \\
Males & & 22.9 \\
Age & 168 & \\
25 and under & 50 & 10.8 \\
Above 25 & & 27.5 \\
Student Classification & 23 & 32.6 \\
Freshman & 60 & 28.0 \\
Sophomore & 71 & 1.4 \\
Junior & 61 & 52.3 \\
Senior & 3 & 3.2 \\
Other & & 44.5 \\
Graduation Intention & 114 & \\
Work with a Company & 7 & 95.9 \\
Teach K-12 & 97 & 4.1 \\
Graduate Studies & & \\
Enrollment Status & 209 & \\
Full-Time & 9 & \\
Part-Time & & \\
\end{tabular}

Table 2:

Qualitative Themes on Teacher Quality Component $(n=218)$

Question 1. Describe what a quality teacher means to you?

Themes

Caring for students and their learning

Teaching skills

Content knowledge

34.0

Dedication to teaching and love of work

14.0

Verbal skills

8.0

5.0

Question 2. Identify four most important teacher quality components.

Themes

Caring of students and their learning

Rate $(\%)$

Teaching Skills

89.6

Content Knowledge

83.2

Dedication to teaching $\quad 75.3$

Verbal Skills

75.0 
Table 3:

Distribution of Responses Based on Student Gender (\%)

\begin{tabular}{|c|c|c|c|c|c|}
\hline & \multicolumn{5}{|c|}{ Students will succeed if teachers know how to teach } \\
\hline Gender & SA & $\mathbf{A}$ & $\mathbf{U}$ & $\mathbf{D}$ & SD \\
\hline Female & 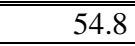 & 25.9 & 7.4 & 5.9 & 5.9 \\
\hline \multirow[t]{2}{*}{ Male } & 51.8 & 25.3 & 6.0 & 4.8 & 12.0 \\
\hline & \multicolumn{5}{|c|}{ Strong verbal skills are key to student achievement } \\
\hline Female & 35.6 & 41.5 & 12.6 & 5.2 & 5.2 \\
\hline \multirow[t]{2}{*}{ Male } & 31.7 & 41.3 & 15.1 & 6.4 & 6.0 \\
\hline & \multicolumn{5}{|c|}{ Good teaching skills will help students learn more. } \\
\hline Female & 68.9 & 20.7 & 2.2 & 2.2 & 5.9 \\
\hline \multirow[t]{2}{*}{ Male } & 48.2 & 33.7 & 1.2 & 7.2 & 9.6 \\
\hline & \multicolumn{5}{|c|}{ Teachers with doctoral degree help students learn more than those without } \\
\hline Female & 3.7 & 3.7 & 18.5 & 34.8 & 39.3 \\
\hline \multirow[t]{2}{*}{ Male } & 8.4 & 8.4 & 15.7 & 31.3 & 36.1 \\
\hline & \multicolumn{5}{|c|}{ Students learn more if teachers know the subject } \\
\hline Female & 64.4 & 23.0 & 5.2 & 1.5 & 5.9 \\
\hline \multirow[t]{2}{*}{ Male } & 50.6 & 28.9 & 7.2 & 4.8 & 8.4 \\
\hline & \multicolumn{5}{|c|}{ Communication is more important than knowledge of subject } \\
\hline Female & 11.1 & 28.9 & 31.9 & 20.0 & 8.1 \\
\hline \multirow[t]{2}{*}{ Male } & 20.5 & 24.1 & 32.5 & 10.8 & 12.0 \\
\hline & \multicolumn{5}{|c|}{ Students learn more when teachers use instructional technology } \\
\hline Female & 10.4 & 31.9 & 40.0 & 12.6 & 5.2 \\
\hline \multirow[t]{2}{*}{ Male } & 10.8 & 31.3 & 43.4 & 10.8 & 3.6 \\
\hline & \multicolumn{5}{|c|}{ Teachers that use all the class time lecturing, help students learn more. } \\
\hline Female & 3.0 & 13.3 & 17.0 & 43.7 & 23.0 \\
\hline \multirow[t]{2}{*}{ Male } & 10.8 & 12.0 & 27.7 & 32.5 & 16.9 \\
\hline & \multicolumn{5}{|c|}{ Students achieve more if teachers give more assignments and home works } \\
\hline Female & 5.2 & 26.7 & 28.1 & 30.4 & 9.6 \\
\hline Male & 15.7 & 25.3 & 30.1 & 21.7 & 7.2 \\
\hline
\end{tabular}

Note: SA - Strongly Agree; A - Agree; U - Undecided; D - Disagree;

SA - Strongly Disagree

Table 4:

Distribution of Responses Based on Student Age (\%)

\begin{tabular}{|c|c|c|c|c|c|}
\hline & \multicolumn{5}{|c|}{ Students will succeed if teachers know how to teach } \\
\hline Age & SA & $\mathbf{A}$ & $\mathbf{U}$ & $\mathbf{D}$ & SD \\
\hline Age $\leq 25$ & 52.4 & 26.8 & 6.5 & 6.5 & 7.7 \\
\hline \multirow[t]{2}{*}{ Age $>25$} & 58.0 & 22.0 & 8.0 & 2.0 & 10.0 \\
\hline & \multicolumn{5}{|c|}{ Strong verbal skills are key to student achievement } \\
\hline Age $\leq 25$ & 29.2 & 42.3 & 17.9 & 6.5 & 4.2 \\
\hline \multirow[t]{2}{*}{ Age $>25$} & 40.0 & 38.0 & 6.0 & 6.0 & 10.0 \\
\hline & \multicolumn{5}{|c|}{ Good teaching skills will help students learn more } \\
\hline Age $\leq 25$ & 62.5 & 24.4 & 1.8 & 4.2 & 7.1 \\
\hline \multirow[t]{2}{*}{ Age $>25$} & 56.0 & 30.0 & 2.0 & 4.0 & 8.0 \\
\hline & \multicolumn{5}{|c|}{ Teachers with doctoral degree help students learn more than those without } \\
\hline Age $\leq 25$ & 6.0 & 5.4 & 17.9 & 32.1 & 38.7 \\
\hline \multirow[t]{2}{*}{ Age $>25$} & 4.0 & 6.0 & 16.0 & 38.0 & 36.0 \\
\hline & \multicolumn{5}{|c|}{ Students learn more if teachers know the subject } \\
\hline Age $\leq 25$ & 56.5 & 26.8 & 7.1 & 3.6 & 6.0 \\
\hline \multirow[t]{2}{*}{ Age $>25$} & 68.0 & 20.0 & 2.0 & -- & 10.0 \\
\hline & \multicolumn{5}{|c|}{ Communication is more important than knowledge of subject } \\
\hline Age $\leq 25$ & 16.1 & 26.2 & 34.5 & 15.5 & 7.7 \\
\hline Age $>25$ & 10.0 & 30.0 & 24.0 & 20.0 & 16.0 \\
\hline
\end{tabular}




\begin{tabular}{|c|c|c|c|c|c|}
\hline & \multicolumn{5}{|c|}{ Students learn more when teachers use instructional technology } \\
\hline Age $\leq 25$ & 11.9 & 29.8 & 41.7 & 11.9 & 4.8 \\
\hline \multirow[t]{2}{*}{ Age $>25$} & 6.0 & 38.0 & 40.0 & 12.0 & 4.0 \\
\hline & \multicolumn{5}{|c|}{ hers that use all the class time lecturing, help students learn more } \\
\hline Age $\leq 25$ & 6.5 & 11.3 & 22.0 & 39.3 & 20.8 \\
\hline \multirow[t]{2}{*}{ Age $>25$} & 4.0 & 18.0 & 18.0 & 40.0 & 20.0 \\
\hline & \multicolumn{5}{|c|}{ Students achieve more if teachers give more assignments and home works } \\
\hline Age $\leq 25$ & 9.5 & 24.4 & 28.6 & 28.0 & 9.5 \\
\hline Age $>25$ & 8.0 & 32.0 & 30.0 & 24.0 & 6.0 \\
\hline
\end{tabular}

Note: SA - Strongly Agree; A - Agree; U - Undecided; D - Disagree; \& SD - Strongly Disagree.

Table 5:

Distribution of Responses by Business Students to Teacher Qualifications, and Teaching Practices Components. (\%) Teacher Qualifications:

\begin{tabular}{|c|c|c|c|c|c|}
\hline & $\begin{array}{l}\text { Strongly } \\
\text { Agree }\end{array}$ & Agree & Undecided & Disagree & $\begin{array}{l}\text { Strongly } \\
\text { Disagree }\end{array}$ \\
\hline $\begin{array}{l}\text { Students will succeed if teachers know } \\
\text { how to teach. }\end{array}$ & 53.7 & 25.7 & 6.9 & 5.5 & 8.3 \\
\hline $\begin{array}{l}\text { Strong Verbal Skills are key to Student } \\
\text { Achievement. }\end{array}$ & 31.7 & 41.3 & 15.1 & 6.4 & 5.5 \\
\hline $\begin{array}{l}\text { Good teaching skills will help students } \\
\text { learn more. }\end{array}$ & 61.0 & 25.7 & 1.8 & 4.1 & 7.3 \\
\hline $\begin{array}{l}\text { Teachers with terminal degree help } \\
\text { students learn more than teachers } \\
\text { without terminal degree. }\end{array}$ & 5.5 & 5.5 & 17.4 & 33.5 & 38.1 \\
\hline $\begin{array}{l}\text { Students learn more if teachers know } \\
\text { the subject well. }\end{array}$ & 59.2 & 25.2 & 6.0 & 2.8 & 6.9 \\
\hline $\begin{array}{l}\text { Communication is more important than } \\
\text { knowledge of what to teach. }\end{array}$ & 14.7 & 27.1 & 32.1 & 16.5 & 9.6 \\
\hline $\begin{array}{l}\text { Subject knowledge is as important as } \\
\text { knowing how to teach. }\end{array}$ & 35.8 & 34.9 & 12.8 & 9.6 & 6.9 \\
\hline
\end{tabular}

\begin{tabular}{|c|c|c|c|c|c|}
\hline \multicolumn{6}{|c|}{ Teaching Practices } \\
\hline $\begin{array}{l}\text { Students learn more when teachers use } \\
\text { instructional technology. }\end{array}$ & 10.6 & 31.7 & 41.3 & 11.9 & 4.6 \\
\hline $\begin{array}{l}\text { Teachers that use all the class time } \\
\text { lecturing, help students learn more. }\end{array}$ & 6.0 & 12.8 & 21.1 & 39.4 & 20.6 \\
\hline $\begin{array}{l}\text { Students achieve more if teachers give } \\
\text { more assignments and home works. }\end{array}$ & 9.2 & 26.1 & 28.9 & 27.1 & 8.7 \\
\hline $\begin{array}{l}\text { Teachers that grade students on exams } \\
\text { alone are ineffective teachers. }\end{array}$ & 12.8 & 22.9 & 28.9 & 24.3 & 11.0 \\
\hline
\end{tabular}

Table 6:

Perceptions of College Students on Teacher Quality Components $(\mathbf{n}=218)$

Variables

Teaching Skills

Commitment to Student Learning

Frequencies (\%)

86.7

Subject Knowledge

86.2

Verbal Skills

84.4

Instructional Technology

73.7

Terminal Degree

$(71.6)^{*}$

\footnotetext{
* negative response from students.
} 